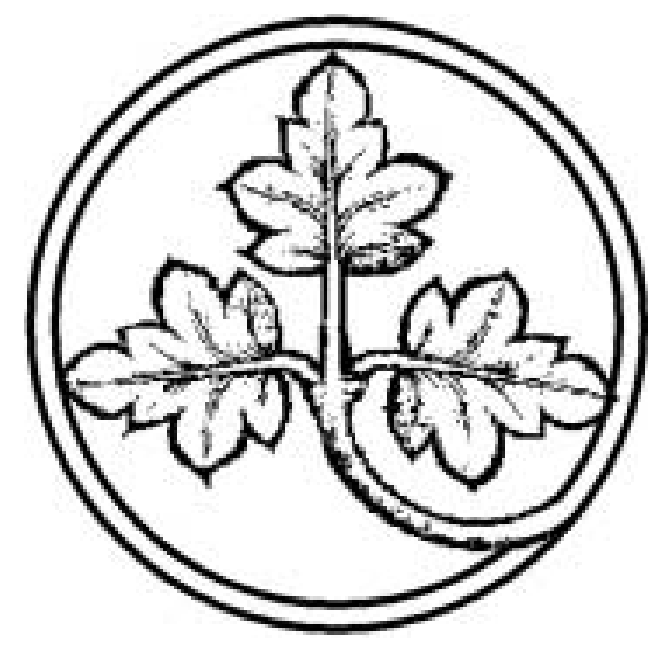

Gemeinschaftsgüter: Recht, Politik und Ökonomie

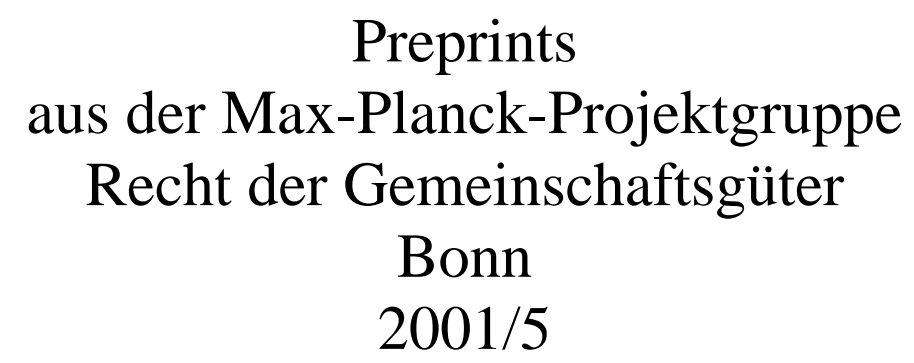

Bringing Together or Driving Apart the Union? Towards a Theory of Differentiated Integration

\author{
von \\ Alkuin Kölliker
}




\title{
Bringing Together or Driving Apart the Union? Towards a Theory of Differentiated Integration
}

\author{
Alkuin Kölliker
}

May 2001

Max-Planck-Projektgruppe Recht der Gemeinschaftsgüter, Poppelsdorfer Alle 45, 53115 


\section{INTRODUCTION - FILLING A GAP IN INTEGRATION THEORY}

With the Treaty of Nice, the European Union ${ }^{1}$ has embarked on the fourth round of comprehensive reforms of its constitutional framework since the relance of integration in the mid-eighties. The unanticipated boost for European unification during the past fifteen years went hand in hand with an increase in institutional flexibility, that is, the possibility for different member states to have different rights and obligations with respect to different policy areas.

The simultaneous progress of integration and flexibility (or differentiation) raises a series of questions on the causal relation between the two. What is the impact of differentiation on integration across different policy areas and member states? More specifically, do flexible arrangements of the willing have centripetal or centrifugal effects on initially unwilling outsiders? And, as a corollary of the previous questions, what are the prospects for the preservation of long run unity within the EU? Does institutional flexibility lead to a positive dynamic of integration, to a negative dynamic of disintegration, or to uneasy and lasting divisions within the Union?

Since the literature has produced few satisfactory, systematic and theory-based answers to these questions so far, a theory of differentiated integration will be presented, developed on the basis of theories of collective action, and in particular public goods theory. The theory suggests that short run differentiation is not necessarily as incompatible with long run unity as is sometimes presumed. Under certain conditions, the long run unity of the Union is likely to be re-established at a higher level of integration, even though differentiation is applied in the short run.

In order to explain the progress of integration across the different issue-areas and member states, the theory relies on a combination of three factors: (1) the flexibility of institutions, (2) the initial willingness of actors and (3) the character of the issue-area in terms of public goods theory. While the first two factors - original political preferences of the member states and the legal possibilities for differentiation - explain why some members may go ahead of others, public goods theory helps to understand (and maybe anticipate) why initially reluctant outsiders end up joining some flexible arrangements, but not others. The theory argues that the centripetal effects providing outsiders with an incentive to join 
depend on the character of the issue-area in question, that is on the type of good the respective policy represents. Among six possible types of goods, excludable network goods develop the strongest centripetal effects, followed by club goods. Private goods take an intermediate position, whereas the centripetal effects of public goods and non-excludable network goods are equally low. Common pool resources (CPRs) rank at the bottom of the list and may even involve centrifugal effects. Flexible arrangements with strong centripetal effects may lead to the eventual participation of most or all members, and therewith to the re-establishment of long run unity at the relatively high level of integration chosen by the most willing members. ${ }^{2}$

Following the presentation, four different EU policies will be discussed in the light of the theory. The focus will be on the single currency as the most significant flexible arrangement within Community law so far. In order to broaden the perspective, three other integration projects will be analysed more briefly, namely the policy against harmful tax competition (harmonisation of taxes on savings), the Schengen Information System (SIS) and the asylum rules of the Schengen and Dublin Conventions. Empirical evidence, though incomplete and preliminary at this stage, suggests that the theory may be a valuable complementary contribution to the understanding of certain integration outcomes which other approaches would have more difficulty explaining. The Euro, the SIS and the Schengen (later Dublin) rules on asylum, three policy areas with certain characteristics of excludable network goods, have developed strong centripetal effects on initially reluctant member states. The elimination of harmful tax competition represents the opposite case. No matter whether their awareness of the common pool resource character of this issue-area was conscious or unconscious, willing member states have not dared so far to proceed on the basis of a small coalition of the willing. Instead, efforts have been concentrated on the search for the most inclusive framework for cooperation in this particular field. Attempts to include all member states and even certain non-EU members are very much in line with the logic of the theory. The cases selected represent extreme cases and neglect policy areas in which, from a theoretical point of view, neither strong centripetal nor centrifugal effects can be expected. This approach has the advantage that clearer results can be expected, which is necessary at this stage, given the very low number of cases taken into account. 
The contribution concludes with a summary of the theoretical and empirical results, while also briefly discussing potential implications for the EU as a producer of publicly provided goods.

\section{THE MISSING LINK BETWEEN DIFFERENTIATION AND INTEGRATION}

Many consider the questions raised in the introduction as some of the most important in the context of flexibility. Answers might be expected both from the specialised literature on differentiation and from integration theories. As we will see, neither of the two strands of literature has provided fully satisfactory responses so far. While the term of integration does not need to be further specified at this point, the concept of differentiation calls for some previous clarifications as to its nature and definition, but also concerning its actual application within the EU.

According to the terminology used in the context of European integration, 'differentiation' constitutes the general term for the possibility of member states to have different rights and obligations with respect to certain common policy areas. The term is often used interchangeably with the concept of 'flexibility' (as in this contribution, too) and subdivided into more specific, but generally less clearly defined sub-categories such as 'variable geometry', 'hard core', 'à la carte', 'different speeds', or 'gravity centre'. ${ }^{3}$ One of the cornerstones upon which the Treaties of Paris and Rome have based the three European Communities was the principle of equal rights and obligations for all member states. The introduction on a large scale of more and more elements of legal differentiation, in particular since the Treaty on European Union, has challenged this orthodox doctrine. ${ }^{4}$ Figure 1 shows one possible way to conceptualise graphically the fundamental difference between a flexible political entity and other forms of governance, such as unitary states, federal states, or simply independent states without strong institutional links between them. ${ }^{5}$ 
FIGURE 1

THE FLEXIBLE UNION COMPARED WITH OTHER MODELS OF GOVERNANCE
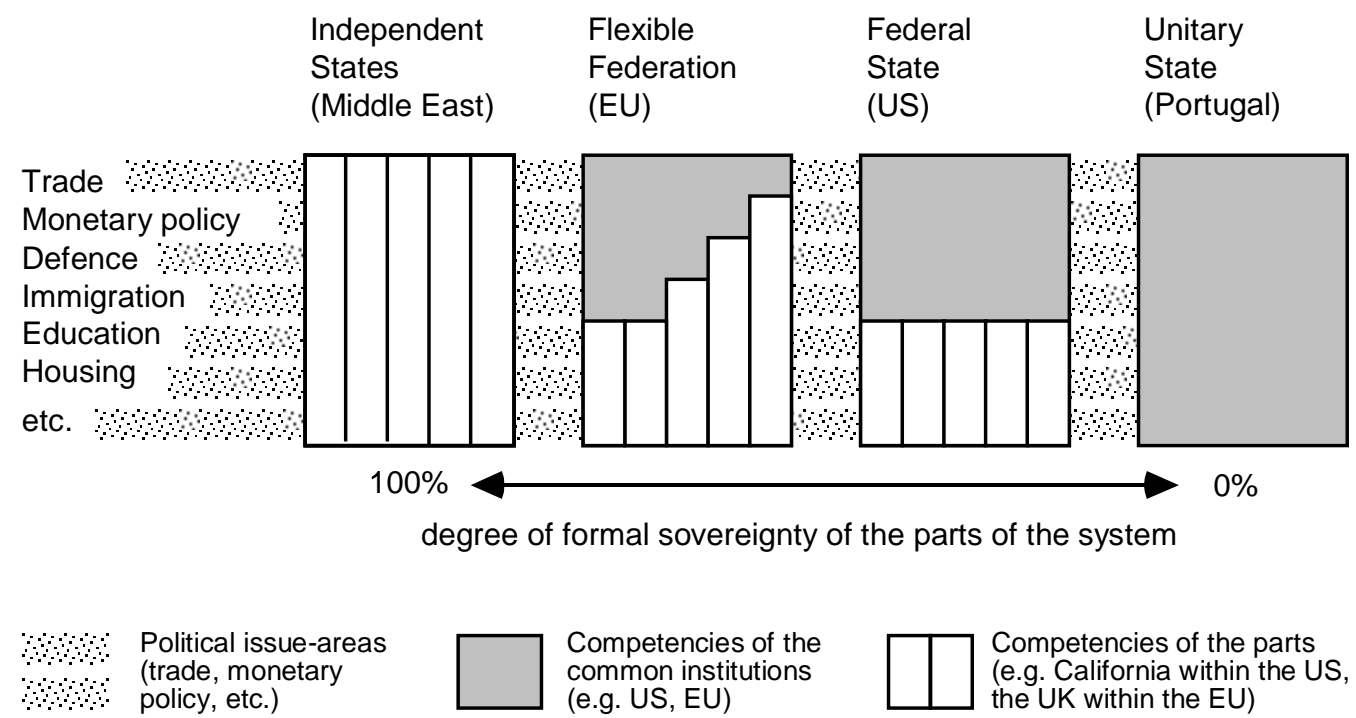

Competencies of the
common institutions (e.g. US, EU)

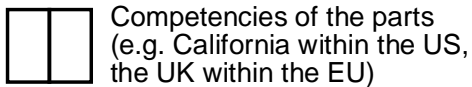

Large-scale application of differentiation was initially being discussed as a theoretical possibility after the first enlargement. The Maastricht Treaty has provided for "predetermined flexibility' (that is, defined by the treaty itself, and applied mainly in the area of monetary, social and defence policy). Prudently, the Amsterdam Treaty has introduced 'enabling flexibility' (allowing for the establishment of flexible arrangements without fixing in advance in which policy areas) in the first and the third pillars, while the Nice Treaty facilitates the application of such differentiation and extends its scope to the second pillar (CFSP). Figure 2 gives an overview of the main examples of pre-determined flexible arrangements within the EU and the respective participants. 


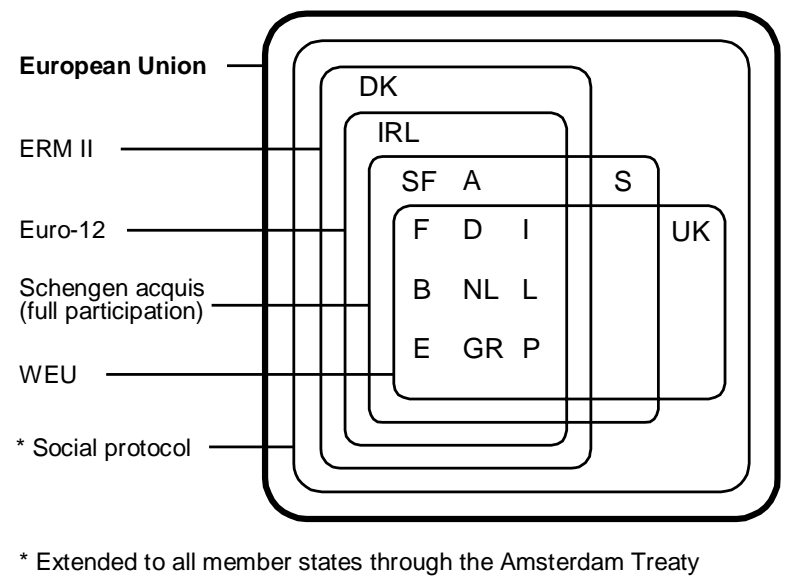

After this very cursory look at the definition and application of differentiation, we can now consider whether and how the existing literature has dealt with the impact of differentiation on integration. In quantitative terms, the literature on differentiation has produced much in the field of description and conceptualisation, somewhat less concerning the origins of flexibility, and relatively little on its consequences. Measured against the importance that political debate and speculation have attributed to the effects of flexibility on integration and unity, the acquis académique in this particular field remains to be further developed. ${ }^{6}$ Perhaps even more disappointing is the failure of integration theories to include within their framework differentiation as a new explanatory variable. While EMU, Schengen and the WEU have been looming large in political debates during the 1990s, the fact that all three involved some form of pre-determined flexibility has received inadequate if any attention in the further development of integration theories. ${ }^{7}$ Possibly due to insufficient communication between the two relevant literatures, no specific theory on the effects of differentiation on integration has been developed so far, nor has the empirical fact of flexibility within the EU been sufficiently integrated in the existing more general theories of European integration. The lack of a theory-based approach sufficiently general and at the 
same time explicit in linking differentiation and integration might be partly responsible for the inadequate assessment of the dynamics of European integration in some areas - and its stagnation in a few others - throughout recent years.

\section{BUILDING A THEORY OF DIFFERENTIATED INTEGRATION}

The theory developed in the following leads to a model indicating the likely integration outcome for specific combinations of three explanatory factors, namely (1) the flexibility of institutions, (2) the willingness of actors and (3) the character of the issue-area in terms of public goods theory. ${ }^{8}$ The main focus is on the influence of the character of the issue-area in the case of flexible institutions and initially unwilling member states. The theory links the taxonomy of goods developed by economists with a framework for analysing collective action problems provided by Schelling. ${ }^{9}$

\section{Concepts: Three variables and related terms to explain integration}

The dependent variable, the eventual level of integration across EU member states and issue-areas, shall be defined as the binary choice of a member between participation and non-participation with regard to an integration project in a specific issue-area. In relative terms, integration is therefore high in the participating countries, low in the nonparticipating countries (and across the whole Union if a project fails altogether). Unity is a corollary of the level of integration across member states and issue-areas. Safeguarded if differentiated agreements fail, while being re-established if all member states participate, the unity of EU law depends positively on the number of member states sharing the same level of integration (be it high or low).

The three independent variables relate to specific properties of institutions, actors and issue-areas in European politics. With respect to the flexibility of institutions, the theory makes only a statement about a specific, yet very important type of differentiation. It includes cases where differentiation (1) is motivated by unwillingness rather than inability, (2) is unlimited in time from the legal point of view (3) applies to whole member states, not just to regions within them and (4) takes place either inside or outside EU law, but in the 
context of European integration and involving member states of the Union. The willingness of actors is defined by the initial preferences of the member states with respect to integration in a specific policy area, the choice being between participation and the status quo (where none of the members cooperates). The third independent variable, the character of the issue-area, is the most complex both in terms of definition and measuring. An empirical assessment and the establishment of a theoretical link with integration outcomes require the use of some related concepts, mainly borrowed from public goods theory, which shall be explained in the following.

Common policies usually consist of a series of measures, which may lead to a variety of effects on the member states. In economic theory, effects on non-participants are termed 'externalities' or 'external effects'. ${ }^{10}$ Analogously, effects on participants shall be called 'internal effects'. The pattern of these effects on the actors, whether real or perceived, whether potential or actual, is the basis for assessing the character of policies. Public goods theory classifies goods according to the two criteria of excludability and rivalry in consumption. Since European policies can be seen as goods produced and consumed in common by EU member states, the terminology of public goods theory may be applied for analytical purposes. Excludability measures whether free-riding is possible, i.e. whether or not outsiders can be excluded from the benefits of a specific good. ${ }^{11}$ The level of rivalry in consumption indicates whether consumption of a certain good is rival, neutral, or even complementary. ${ }^{12}$ Consumption is rival if an additional consumer decreases the utility of a specific unit of good for other consumers (food, social benefits), neutral if the utility remains the same (websites, TV programs), and complementary if the utility increases (languages, technical standards). The result of this two-dimensional classification is a table with six categories of goods, representing the character of policies in terms of public goods theory. As we will see, the theory allows ranking these six types of goods (respectively policies) according to their centripetal effects on non-participants. Centripetal effects shall be defined as follows: the smaller the core of cooperating member states necessary to give initially unwilling outsiders the incentives to join in, the stronger the centripetal effects of the respective policy. The six types of goods will now be briefly introduced to and illustrated by examples from the EU context. 


\section{Public goods theory: Definitions and examples}

Economic theory defines private goods as goods where the exclusion of potential free riders can be easily achieved and rivalry in consumption is high. The EU's Common Agricultural Policy (CAP) has strong characteristics of a private good, since the subsidies distributed across different countries are rival and excludable.

Club goods are goods from which exclusion is possible while the rivalry in consumption tends to be low. ${ }^{13}$ In the EU context, the free movement of persons between member states has certain aspects of a club good. At the external borders, participant countries can deny access to nationals of non-participant countries, while the benefits are not necessarily rival. The EU as such, but also other forums at the international level, are frequently referred to as 'clubs'. ${ }^{14}$ In some cases this refers more or less directly to certain club characteristics as defined by public goods theory.

Exclusion from excludable network goods is by definition easy, while consumption is not just not rival, but even complementary: additional users add to the benefit other users draw from the good. ${ }^{15}$ Probably the most straightforward example of an excludable network good in the EU so far is the Schengen Information System (SIS), which pools crime-related information provided by national police forces. ${ }^{16}$ The case study on EMU will show that the single currency has also strong aspects of an excludable network good for EU members.

Common pool resources (CPRs) are non-excludable goods with rival consumption. ${ }^{17}$ In the absence of strong institutions, such as a rule of binding majority decisions combined with enforcement mechanisms, common pool resource problems tend to lead to regulatory competition. ${ }^{18}$ EU policies aiming at the prevention of what some have called 'social, fiscal and monetary dumping' in fact involve common pool resource problems. ${ }^{19}$ More specifically, those policies try to restrain member states from race-to-the-bottom deregulation, harmful tax competition and competitive currency de-valuations (we will come back later to the last two points). Environmental policies dealing with cross-national pollution, in particular policies addressing the problem of climate change, belong to the same category.

Exclusion from public goods is difficult to achieve, while consumption is neutral. The promotion of stability and peace constitutes a public good for countries in Europe, since there are also important benefits for free-riders, in particular those countries bordering 
mainly EU member states. While it may be difficult to exclude certain non-participants from these benefits, peace and stability tend at the same time to be non-rival goods.

Finally, the prevention of free-riding tends to be costly in the case of non-excludable network goods, while additional users add to the utility other users can draw from the product. In the context of EU policies, setting technical product standards can constitute a non-excludable network good, from which industries and consumers outside may profit as much as those inside. In the meantime, the utility of standards depends on the number of users applying them.

FIGURE 3

CATEGORIZATION AND EXAMPLES OF GOODS IN ECONOMIC THEORY

\begin{tabular}{|c|c|c|c|}
\hline & & \multicolumn{2}{|l|}{ Excludability } \\
\hline & & High & Low \\
\hline \multirow[t]{3}{*}{$\begin{array}{l}\text { Consump- } \\
\text { tion }\end{array}$} & Rival & $\begin{array}{l}\text { Private goods } \\
\text { (cohesion fund) }\end{array}$ & $\begin{array}{l}\text { Common pool resources } \\
\text { (mobile tax basis) }\end{array}$ \\
\hline & Neutral & $\begin{array}{l}\text { Club goods } \\
\text { (free movement of persons) }\end{array}$ & $\begin{array}{l}\text { Public goods } \\
\text { (peace-keeping) }\end{array}$ \\
\hline & $\begin{array}{l}\text { Comple- } \\
\text { mentary }\end{array}$ & $\begin{array}{l}\text { Excludable network goods } \\
\text { (Schengen Information System) }\end{array}$ & $\begin{array}{l}\text { Non-excludable network goods } \\
\text { (technical product standards) }\end{array}$ \\
\hline
\end{tabular}


Introducing the model: From basic assumptions to the impact of flexibility

What is the combined effect of flexibility, willingness, and the character of policies on the eventual outcome? The model in Figure 4 represents a summary and overview of the theory of differentiated integration as it will subsequently be deduced. The outcome in terms of integration and unity will be explained step by step, starting with the case without flexibility (left-hand side in Figure 4) and ending with the combination of flexible institutions, initially unwilling member states, and the different types of policies (right-hand side). The model makes clear that, for a given set of preferences among the member states, the outcome can differ fundamentally depending on the flexibility of institutions and the character of the policy in question.

It is important, however, to keep in mind that the theory rests upon a series of restrictive assumptions. First of all, the theory is deduced for the pure forms of the six categories of goods. In practice, most policies have a mixed character. However, as long as one aspect is predominant, the theory nevertheless remains applicable. Second, it is assumed that actors behave rationally and maximise their utility (rational choice theory). Third, the member states are the decisive actors and act as unitary entities. At the constitutional level of the EU, where member states take decisions by unanimity and have the last word, this classical assumption of intergovernmental and realist theories of international relations still comes fairly close to the truth. Fourth, the fundamental preferences of the member states do not change in the course of the analysed time period, and neither issue-linkage nor equivalent techniques are applied. This does not of course mean that changes in preferences and package deals do not occur in reality, but it makes clear that these variables are to be controlled for. The same applies also to the fifth assumption, according to which each proposal for further integration has a number of supporters while there is also at least one initially reluctant member state. 
FIGURE 4

A MODEL OF FLEXIBLE INTEGRATION

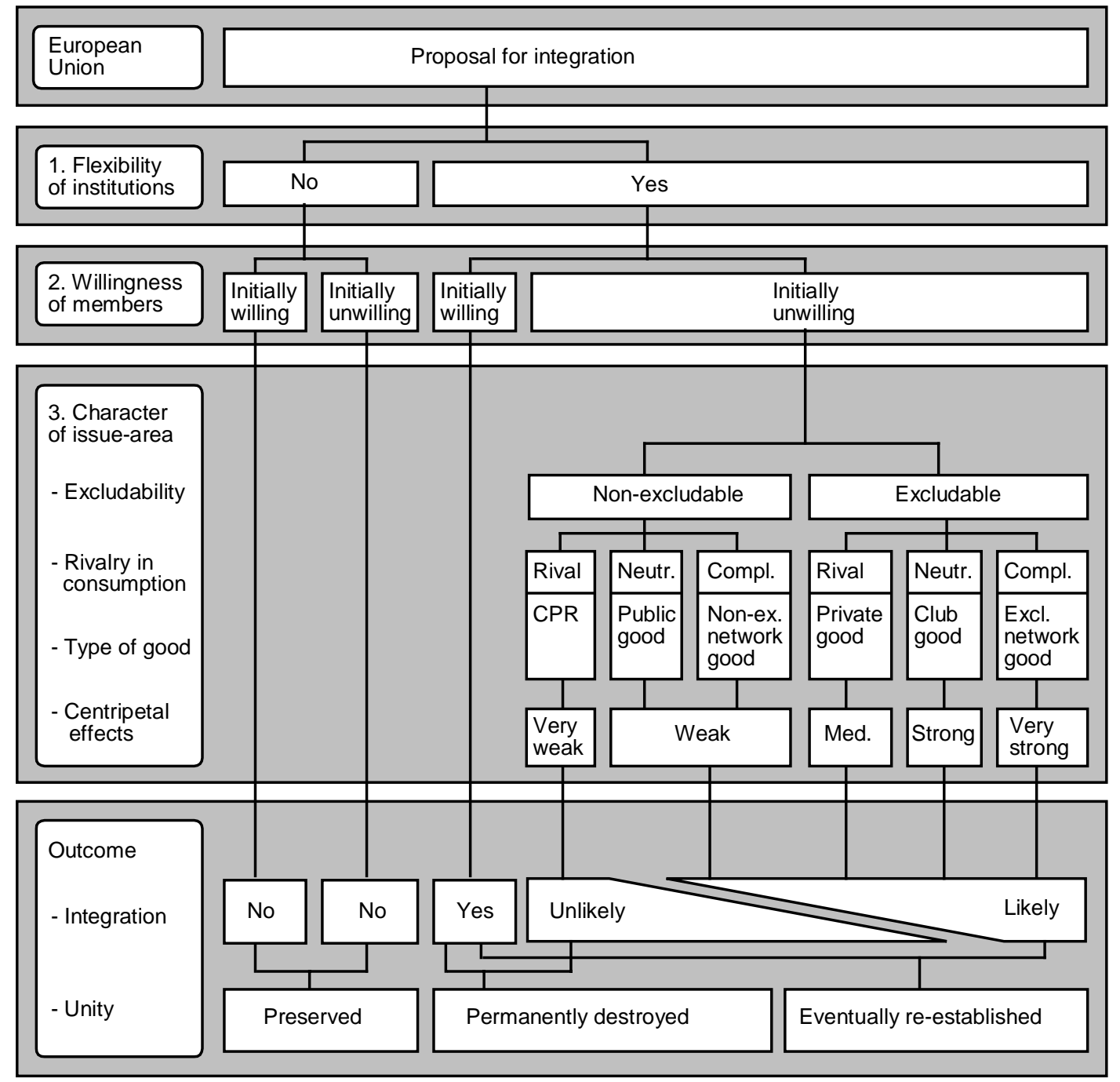

If differentiation is ruled out for legal or political reasons and if neither issue-linkage nor equivalent techniques are applied, any unwilling member may block a proposal for further integration. In this case, neither initially willing nor initially unwilling members will integrate their policies in the respective field. As a result, the level of integration remains low across the whole Union while the unity of the EU legal system is preserved. If differentiation is applicable, the conditions for integration become more relaxed, since 
initially willing countries may integrate their policies even though other countries are initially unwilling. Whether the latter will eventually be willing to follow depends strongly on the character of the issue-area. If centripetal effects induce outsiders to follow, the unity of law will eventually be re-established at a uniform and higher level of integration, otherwise it will remain permanently destroyed. Now the question is how the character of a policy influences the centripetal effects which give initially unwilling outsiders the incentives to join in eventually.

\section{Ranking centripetal effects: The impact of the character of policies}

In order to rank the six types of goods according to their centripetal effects, I will rely on a slightly modified form of a framework that has been developed by Schelling and applied by Genschel and Plümper. ${ }^{20}$ By means of this framework, it can be shown graphically how the eventual participation of an initially unwilling member is influenced by excludability and rivalry in consumption - in other words by the character of the good.

Schelling has used diagrams to represent separately the utility of cooperation and noncooperation for a given country, depending on the number of cooperating actors, usually assuming utility to be increasing with an enhanced number of participants. ${ }^{21}$ While Genschel and Plümper, too, have taken this assumption as their point of departure, it remains legitimate to ask why this should actually be the case. Two arguments can be made in this respect.

The first argument is the fact that in the case of non-rival consumption, costs can be shared among more and more participants, while benefits remain the same (neutral consumption) or do even increase (complementary consumption). This is a point on which we will come back soon. On the same basis, it can be argued that in the case of rival consumption the utility of participation remains stable, independently of the number of participants. This applies certainly to private goods. If each new member contributes the same quantity of the good, the total amount will increase, but since benefits have to be shared and are rival, individual benefits will neither increase nor decrease. Common pool resources are a special case that will be dealt with a little later. 
The second argument concerns negative effects of participation respectively abstention. On one hand, an important negative effect of non-participation that applies independently in all issue-areas is the international isolation that is often bemoaned even by the outsiders themselves. On the other hand, participation involves limiting the freedom of action enjoyed by states, mostly perceived as a (negative) "loss of sovereignty". But while the suffering from isolation tends to increase with a growing number of participants, the loss of freedom of action remains the same or becomes even less disturbing as other countries make the same sacrifices. These effects tend to be important ones and they apply basically in all policy areas, independently of the character in terms of public goods theory. An increasing number of participants therefore tends to make participation more attractive for the remaining outsiders. This second argument is in fact the reason why the net benefits of participation as depicted on the right-hand side of Figure 5 (see below) are sloping slightly upwards even in the case of rivalry in consumption. But whatever the general impact of the number of participants on the utility of participation and non-participation, the order of ranking of the six goods which follows now remains in any event unaffected by these considerations.

For the further analysis I shall use modified Schelling diagrams representing opportunity costs for initially unwilling outsiders. Economic theory defines opportunity costs as the difference in utility between one option and the best available alternative option. In our case the opportunity costs are the positive and negative 'internal effects' of participation minus the positive and negative 'external effects' of remaining outside while others cooperate. It is these net benefits of participation (in comparison with non-participation) which will be represented in the modified Schelling diagrams upon which the further analysis is based. Initially unwilling outsiders are expected to participate as soon as the net benefits of participation turn positive.

According to the definition made earlier, strong centripetal effects mean that a relatively small core of cooperating countries is sufficient to give initially unwilling countries the incentive to participate..$^{22}$ Put differently, the quicker net benefits of participation for initially unwilling outsiders turn positive as the number of participants increases, the stronger the centripetal effects. In the following, it will be shown how the different categories of goods can be distinguished and ranked according to their centripetal effects. 
Figure 5 shows how excludability and rivalry in consumption influence the net benefits of participation as the number of participants rises from the minimum to the potential maximum. While the tendencies described below apply to all initially reluctant outsiders, the precise position of the utility curves may differ from one country to the other. It is not presumed that the preferences of all outsiders are homogeneous. ${ }^{23}$

FIGURE 5

NET BENEFITS OF PARTICIPATION: THE INFLUENCE OF EXCLUDABILITY AND RIVALRY IN CONSUMPTION

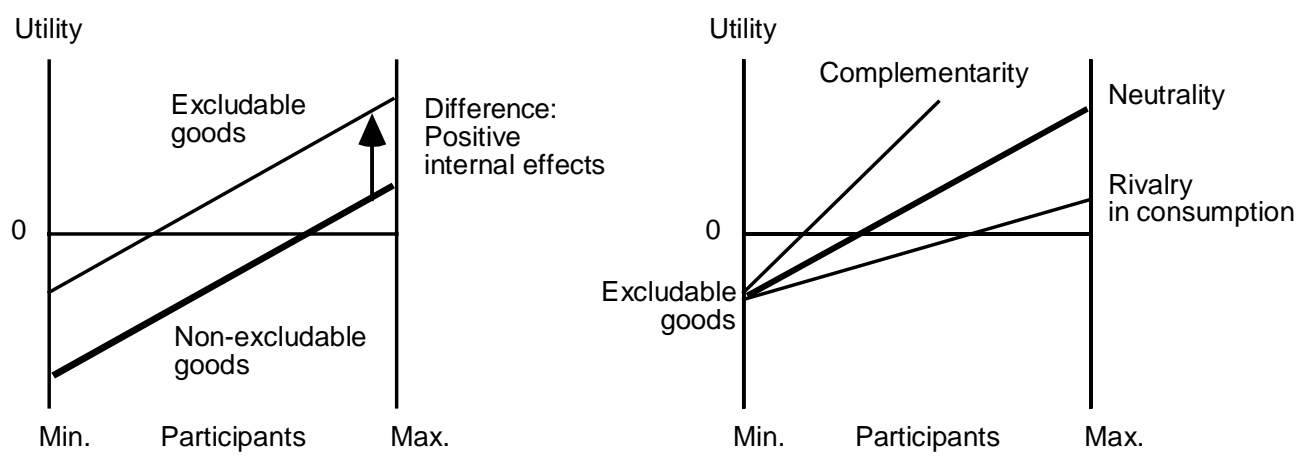

The diagram on the left shows that, under otherwise equal circumstances, the eventual participation of initially reluctant members is more likely in the case of excludable goods. Since outsiders cannot free-ride on the efforts of participants, their incentive to join is higher than in case of non-excludable goods, where free-riding is possible. Pure nonexcludable goods are defined by the fact that positive external effects (for outsiders) are just as high as positive internal effects (for the participants themselves). By contrast, if full exclusion is possible, there are no positive external effects whatsoever. The difference between pure excludable and non-excludable goods is therefore equivalent to the positive internal effects. 
The diagram on the right shows the impact of rivalry in consumption for excludable goods. If consumption is neutral (club good), positive internal effects remain the same while the number of participants increases. The slope remains therefore similar to that in the diagram on the left. If consumption is rival (private goods) the slope is less steep, since the positive effects must be shared among an increasing number of participants. ${ }^{24}$ By contrast, if consumption is complementary (excludable network goods), the slope is steeper, because the positive internal effects increase more quickly as the number of participants increases. In the case of the three non-excludable goods, the degree of rivalry in consumption as such has no impact on the development of the net benefits of participation. Whether consumption is rival or complementary, the influence on the net benefits of participation is cancelled out. As explained in the previous paragraph, changes regarding positive internal effects inevitably lead to equivalent changes in positive external effects.

Two additional considerations allow the ranking of private goods, respectively CPRs, more precisely in relation to other types of goods. With respect to private goods, it has been shown that the difference in the net benefits of participation between excludable goods (including private goods) and non-excludable goods corresponds to the positive internal effects of participation (see Figure 5). Although decreasing because of rivalry in consumption, this difference will always be positive. Other things being equal, the net benefits of participation for private goods are therefore always superior to those for nonexcludable goods (see Figure 6 further down). While the differences between the other goods have so far been directly deduced from their definition in terms of public goods theory, the following remark flows from a practical consideration of the particular nature of common pool resources. As their name already suggests, CPRs represent a special case in that they involve in most cases the sustainable exploitation rather than the actual production of a good (e.g. fishing grounds, oilfields, mobile tax basis). ${ }^{25}$ Since this requires a certain degree of self-restriction, free-riders can potentially profit even more than participants from the benefits of cooperation. Hence, positive external effects tend to be higher than positive internal effects. Moreover, higher participation further reinforces this positive tendency for the outsiders. As a result, the centripetal effects of CPRs rank even lower than those of the other two types of non-excludable goods. 
The results can now be summarised, and the six categories of goods be ranked according to their centripetal effects (see Figure 6). In the case of excludable network goods the centripetal effects are strongest, since increasing participation leads to rapidly growing benefits while free-riding is difficult. Club goods and private goods rank second and third respectively. Non-excludable network goods and public goods follow, ranking equally. CPRs involve the weakest centripetal effects, as exclusion is impossible and the benefits for outsiders are potentially higher than for self-restrictive cooperators. To the extent that incentives for outsiders to join might sometimes become weaker rather than stronger as the number of participants increases, one could even speak of centrifugal effects.

FIGURE 6

RANKING GOODS ACCORDING TO CENTRIPETAL EFFECTS

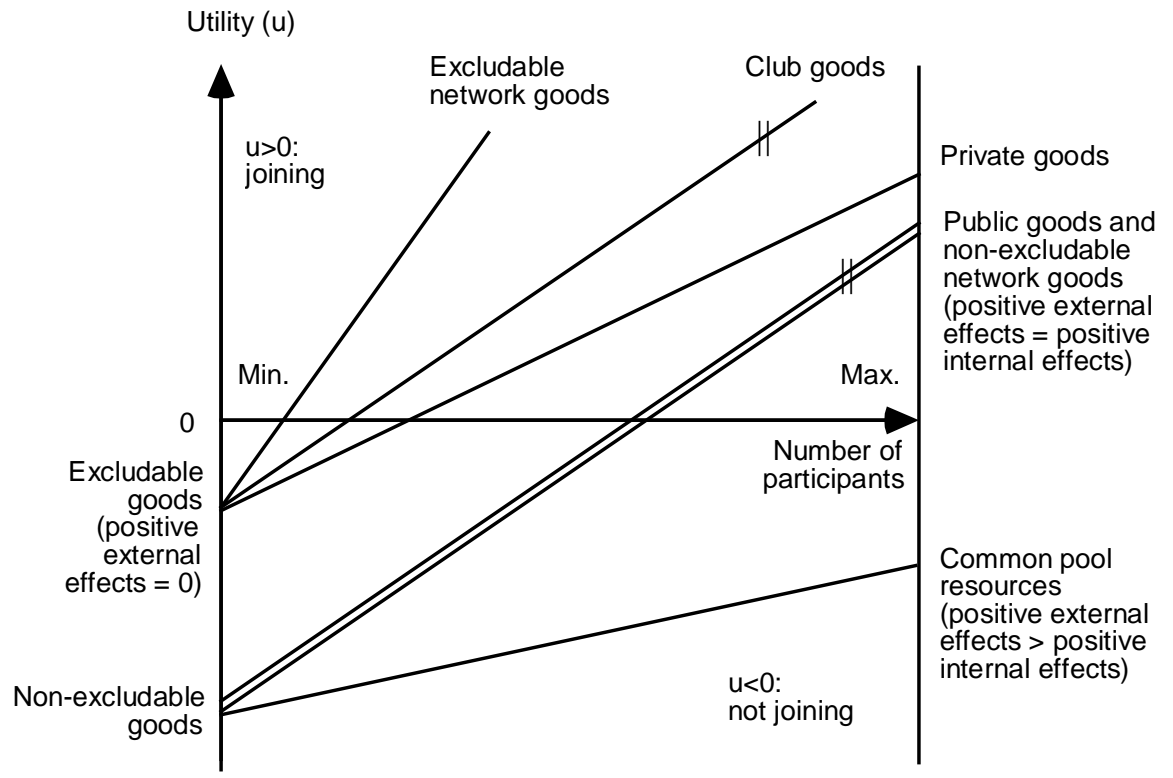

Propositions: What follows for integration and unity

On the basis of the theoretical reasoning that has just been presented, the following main propositions can be drawn from the model (see again Figure 4 while keeping in mind the restrictive assumptions made previously): 
1. If differentiation is not applicable, the level of integration in any given issue-area will remain low, excepts for if support among member states is unanimous or if issuelinkage (or an equivalent technique) is applied.

2. If differentiation is applicable, integration may take place among a group of initially willing member states despite the reluctance of initially unwilling members. The outcome in terms of integration goes beyond the lowest common denominator of the member states (and probably even of the participating countries, since hesitant wouldbe participants may be threatened with exclusion by the even more integration-minded).

3. For initially unwilling member states, the likelihood of their eventual integration is influenced by the character of the issue-area. Centripetal effects are strongest in case of excludable network goods, followed by club goods, private goods, and public goods/non-excludable network goods. CPRs rank lowest and may even involve centrifugal effects.

4. The corollary of the above propositions is that unity within the EU tends to be (a) preserved at a low level of integration if differentiation is not applicable, (b) permanently destroyed at a mixed level of integration if differentiation involves issue-areas with weak centripetal effects, and (c) eventually re-established at a high level of integration if differentiation involves issue-areas with strong centripetal effects.

At this stage, the theory does not specify how much time may pass until initially reluctant countries eventually participate. If reluctant member states are able to anticipate centripetal effects, their first best strategy would be to try to veto the creation of a flexible arrangement, while the second best solution would be to join immediately. While both of these reactions could sometimes be observed (how else to explain either the Amsterdam "veto clause" concerning closer cooperation or the British ratification of the Single European Act despite serious misgivings about its supranational drive?), the 'wait and see' strategy seems to be even more frequent. This is because, in general legal terms, flexible integration can be vetoed only if it takes place within EU law. Moreover, reluctant countries often hope for and bet on the non-implementation of engagements made by the more willing member states. They do not wish to reinforce the drive towards integration through showing premature enthusiasm. Thus, eventual participation can be expected only 
after initially reluctant countries are convinced that integration goes really ahead even without them. Further delays may arise if reluctant members wait for the actual external effects to develop instead of deciding on the basis of mere expectations. Last but not least, domestic ratification procedures take time even after governments have finally taken their decision. Thus, if a reluctant country does not join immediately on the basis of expectations about the future, the delay before 'eventual participation' may easily be several years. It can be expected, however, that the whole process remains a medium-term matter of years rather than a long-term matter of decades. As a rule of thumb, it should be possible to pass a final judgement about a specific case within much less than a decade.

\section{EMPIRICAL EVIDENCE FROM THE EMU CASE}

Many observers have characterised the move from national currencies to the Euro on 1 January 1999 as the most momentous single event in European integration since the Rome Treaties. Combining a hugely important issue-area with the technique of differentiation, monetary union deserves the particular attention of anyone trying to grasp the relation between flexibility and integration in Europe.

\section{Differentiation and reluctance towards EMU participation}

The Maastricht provisions for the third stage of EMU allow for differentiation within European law and at the constitutional level, concerning member states as a whole, remaining unlimited in time and stretching across an entire policy area. ${ }^{26}$ In short, they represent a combination which previously had never existed. Moreover, the provisions include two sets of flexible arrangements, dealing with both unwillingness and inability of member states. As already pointed out, the theory makes statements relating only to initially unwilling member states, while leaving aside the issue of inability.

After the failure of the Werner Plan in the 1970s, the joint initiative of the governments of

France and Italy in 1988 is usually considered as an important starting point for the more successful second attempt for the creation of EMU. At this point in time, the details of EMU were still very much open to debate, while the preferences of most member states 
were neither clearly defined nor openly stated. But whatever the exact preferences of the Twelve, unanimous agreement upon a concrete and binding blueprint for monetary union, comparable with the single market project in the mid-eighties, was plainly non-existent. Even the Commission, which surely could not be suspected of underestimating member states' eagerness to join EMU, was unable to name more than a handful of fully supportive governments. ${ }^{27}$ Preferences ranged from strong support (Italy, France and Belgium) over certain - sometimes considerable - reservations (Germany, the Netherlands, Luxembourg, as well as some of the economically weaker 'cohesion countries') to downright hostility (Britain and Denmark). The governments of Austria, Finland and Sweden, which were not yet members at that stage and on the average had probably even more reservations than the Twelve, lacked a voice in EMU negotiations. ${ }^{28}$ Objections to monetary union had various sources in the individual member states. They were overcome by different means and to different degrees. Alternative explanations for changing attitudes towards EMU and the role of centripetal effects in this process will be discussed together with the eventual participation in the single currency.

\section{The Euro as an excludable network good}

The progressive establishment of the single currency has been accompanied by a growing literature on its effects. ${ }^{29}$ An assessment of these effects leads to the conclusion that, in comparison with other policy areas, EMU represents predominantly (but not exclusively) an excludable network good. From a theoretical point of view, considerable centripetal effects on outsiders could therefore be expected. The Euro can be considered as an excludable network good to the extent that its utility grows with the number of participants and that non-participating countries are largely being excluded from these positive effects. ${ }^{30}$ As we will see, this is the case in many, but not in all respects.

First of all, the Euro is expected to create positive efficiency and growth effects. The more member states participate, the higher the savings in transaction costs, as well as the dynamic growth effects resulting from more efficiency and increased competition in each of the participating economies. Moreover, the costs caused by the introduction of the Euro tend to decrease (shared costs for common arrangements) or at least remain stable (costs of transition in each country) as the number of participants increases. The Euro has also 
certain network properties with respect to its position in the international system. The importance of the Euro as an international vehicular currency competing with the dollar and the yen increases with the size of the Euro group. Enterprises may save money by doing a bigger share of business in their own currency when dealing with the outside world. The international weight of the single currency was also expected to protect participants from speculative attacks, an argument which has gained currency in the wake of the Asian crisis but remains yet to be confirmed after the recent downward pressures on the Euro. There was also general agreement that with the introduction of the single currency, less external reserves were going to be required. The total share of external reserves which may potentially be reallocated grows with the number of participants. To the extent that the preferences of participating countries converge, a common external representation of Euro12 could also increase their ability to extract benefits from international cooperation in the monetary field, and perhaps beyond. In most of these cases of complementary consumption, free-riding by outsiders appears limited, although not altogether impossible. To the extent that outsiders are excluded from positive effects, the character of EMU resembles an excludable rather than a non-excludable network good.

In one respect though, monetary union may potentially also have the character of a common pool resource with correspondingly weak centripetal effects. EMU precludes any attempts by individual participants to tap export markets through engaging in competitive currency devaluations. The CPR character is due to the fact that export markets represent a rival good from which exclusion is, at least within the internal market, legally impossible. However, three developments put rather narrow limits on the practical relevance of this argument. First, while the net benefits of competitive devaluations have long been subject to debate, more recently they have increasingly come to be seen as close to zero. ${ }^{31}$ Moreover, competitive devaluations have been restricted for some of the 'outs' by the ERM II, the successor of the Exchange Rate Mechanism that had been established in the framework of the European Monetary System (EMS) in 1979. Last but not least, the weak performance of the Euro so far has turned this argument upside down, as the downslide of the single currency has led other currencies to appreciate rather than devaluate. 


\section{Eventual EMU participation and the role of centripetal effects}

Despite initial reluctance in many countries, only the UK, Sweden and Denmark have not yet joined the Euro area so far. Given earlier expectations of a small core of perhaps as few as five participants, this may already be seen as quite a success. Initially, full support for the EMU project was limited to a small group of member states, mainly France, Italy and Belgium. So what accounts for the eventual participation of other member states? It appears that no member state has changed its attitude towards the single currency because of genuine shifts in fundamental preferences. By contrast, compensation through side-payments, package deals or issue-linkage (respectively de-linkage) seem to have had a major impact in the reshaping of some member states' preferences. But explaining participation through compensation has its limits, since some members got only unsatisfactory compensations, and others none.

It seems that the final design of EMU reflected to a very large extent certain initial reservations of some of the Community's founding members. Worried about price stability and eager for political union, Germany and the Netherlands extracted major concessions from their partners, including an intergovernmental conference on political union and Frankfurt as the seat of an independent ECB. Likewise, the reservations of Luxembourg, specifically with respect to the possible transfer of sovereignty in the area of tax policy, were duly taken into account.

The four cohesion countries supported EMU to a various degree, but only under the condition of considerably increased side-payments for less competitive regions. In Portugal and Greece, economically the weakest members of the EU, reservations with respect to EMU were stronger than in Spain and Ireland, which were generally more supportive of European integration. It remains in doubt whether the Delors II package, reinforcing cohesion and negotiated at the same time as monetary union, was in fact so closely linked with monetary union, and whether the package appropriately settled the problems raised by these countries. Many economists have argued that the extent of transfer payments remains considerably below the level required to effectively counterbalance asymmetric productivity shocks. Hence, it seems that at least in the case of Greece and Portugal, compensation through side-payments may not fully explain their participation.

None of the remaining five countries were offered any sort of compensation in case that they were going to participate in EMU. Instead, the UK and Denmark negotiated formal opt-outs under the Maastricht protocols, while Austria, Finland and Sweden were not yet EU members 
when the Treaty on European Union was signed. In legal terms, the three newcomers had to accept the acquis communautaire in full, including monetary union, when they joined on 1 January 1995. However, the example of Sweden (that failed to join the ERM and therewith missed to meet one of the Maastricht criteria) demonstrates that in practice they could invoke inability to join, although being in fact simply unwilling. Hence, actual and potential participation in the five cases mentioned cannot be explained exclusively on the basis of legal obligations and package deals.

A number of reasons may explain why centripetal effects have not (yet) been strong enough to bring the UK, Denmark and Sweden in line with their partners, therewith restoring full EUwide unity in the monetary field. Contrary to all other members, participation of these countries hinges on popular referendums on EMU. It is a well-known fact that in most countries, governments and parliaments are more inclined towards integration than the populations. Had the government had the last word, Denmark would already have joined EMU. Even voters might have endorsed the single currency as such in the (failed) September 2000 referendum, had it not been for the political spillovers it feared. Similar arguments could be put forward in the case of Sweden and the UK. Moreover, the full network effects of EMU will only start to unfold with the introduction of Euro bills and coins in 2002. While it is still too early to draw definitive conclusions, many observers agree that in the long run it will be difficult for the remaining countries to resist the centripetal effects of EMU forever. Despite recent setbacks, the eventual entry of these three countries can therefore still be considered as the most likely outcome in the long run. Yet such a result could be explained neither in terms of initial preferences nor through any kind of compensations.

The analysis, summarised in Table 1, has shown that although only a few member states (particularly France, Italy and Belgium) were fully supportive at the beginning, EMU participation has become a fact for most of them and a likely long run outcome for the rest. While some sort of compensation may sufficiently explain the actual or potential participation of some countries (Germany, the Netherlands, Luxembourg, Spain and Ireland), centripetal effects appear to be better suited in other cases (Austria, Finland, Sweden, Denmark and the UK). In the remaining cases (Portugal and Greece) the two explanations might overlap. 
TABLE 1

EXPLAINING EMU PARTICIPATION: THE ROLE OF CENTRIPETAL EFFECTS

\begin{tabular}{llllll}
\hline Members & & $\begin{array}{l}\text { Initial } \\
\text { willingness }\end{array}$ & Compensation & $\begin{array}{l}\text { Eventual } \\
\text { participation }\end{array}$ & Explanation \\
\hline $\begin{array}{l}\text { Founding } \\
\text { members }\end{array}$ & F, I, B & Favourable & Unnecessary & Yes & Preferences \\
\cline { 2 - 6 } & D, NL, L & Reservations & Satisfactory & Yes & Compensation \\
\hline $\begin{array}{l}\text { 'Cohesion } \\
\text { countries' }\end{array}$ & E, IRL & Reservations & Satisfactory & Yes & Compensation \\
\cline { 2 - 6 } & GR, P & Reservations & Unsatisfactory & Yes & Compensation and \\
& A, SF & Reluctant & None & Yes & Centripetal effects \\
\cline { 2 - 6 } $\begin{array}{l}\text { Other } \\
\text { members }\end{array}$ & DK, S, UK & $\begin{array}{l}\text { Strongly } \\
\text { reluctant }\end{array}$ & None & Likely & Centripetal effects \\
\hline
\end{tabular}

\section{THE CASES OF TAX HARMONISATION, SCHENGEN AND DUBLIN}

After this more detailed presentation of the EMU case, three more arrangements in the EU context shall be briefly discussed in the light of the theory. The examples include tax competition as a CPR problem on one hand, and two Schengen-related arrangements with excludable network effects on the other hand, namely the Schengen Information System (SIS) and the Schengen rules on asylum. The Schengen asylum chapter eventually came to be superseded by the Dublin Convention. This demonstrates that centripetal effects may find their expression not just in the enlargement of existing flexible arrangements, but also in the transfer of the respective issue-area towards a more inclusive framework.

\section{Tax harmonisation as a CPR problem: The anticipated failure of a small core}

The fact that in most cases of common pool resources, public policies are concerned with the preservation and sustainable exploitation rather than the production of a good applies also in the field of tax harmonisation. In trying to limit harmful competition for a tax basis 
that is mobile across borders, therewith maintaining their capacity to impose taxes, EU governments try to solve a common pool resource problem. The CPR character is due to the fact that consumption is rival (different governments being unable to tax all at once) and that the exclusion of non-cooperating countries and jurisdictions from benefits poses enormous difficulties. On the contrary, the potential benefits of tax harmonisation in the form of increased tax revenues for cooperating governments may easily leak to noncooperating countries that establish themselves as tax havens. ${ }^{32}$

Ever since full capital mobility within the single market was established in 1990, some member states have felt that reducing harmful tax competition has become ever more urgent. As certain other member states turned out to be strongly reluctant, and neither issue-linkage (in the context of EMU) nor equivalent techniques were put into operation, it proved extremely difficult to come to any agreement. Strangely enough, flexibility was not applied either, although it had been used as a powerful instrument to break deadlock in fields like monetary integration (EMU), the free movement of persons (Schengen) and defence (WEU). In the absence of differentiation among member states, it appears at first doubtful whether a theory on differentiated integration could be applied to the case of tax harmonisation. However, the theory may contribute to an understanding of why differentiation has not been applied in the first place. It can be concluded from their behaviour that, for some reason, willing member states did not see flexibility as a promising remedy to the deadlock in the area of tax harmonisation. While the empirical evidence in this case is unfit to prove or disprove any actual effects of flexibility, it appears that willing member states expected effects that so far made them renounce to this possibility.

The theory predicts that the eventual integration of initially unwilling member states is most unlikely if CPR problems are involved. Moreover, the benefits cooperators create through their self-restriction in the management of a CPR tend to leak to non-cooperators. These two factors taken together may explain perfectly why differentiation was not used in this area. Hence, in the case of tax harmonisation, the theory does not primarily explain the actual integration outcome. However, it may explain the feedback of the expected integration outcome on using, or more precisely on renouncing to flexibility. 
What has occurred instead in this policy area? For the reasons that have been just mentioned, willing governments shy away from establishing differentiation within the EU. Instedad, they have an incentive to include as many potential free-riders as possible from the outset. This is precisely what appears to be happening in the case of the EU directive on the taxation of savings. In effect, the conclusions of the Feira European Council insist on the participation of all member states and therewith preclude differentiation within the EU. In addition to that, Feira made cooperation among the Fifteen dependent on the 'adoption of equivalent measures' in potential and actual tax havens beyond EU borders (referring explicitly to Switzerland, Liechtenstein, Monaco, Andorra and San Marino as 'key third countries'). ${ }^{33}$ The search for a more inclusive framework has also led to activities at the level of the OECD and even beyond. This strategy reflects closely the logic of the theory. It also contrasts strikingly with the approach of willing members towards EMU and Schengen, where they seem to have expected stronger centripetal effects and did not hesitate to move ahead alone. ${ }^{34}$

\section{Schengen: The eventual success of a small core}

Projects for a European passport union, including the abolishment of border controls between EC members and related policies, date back to the early 1970s. While the founding members were generally supportive, progress was deadlocked for a long time, as the new members (UK, Denmark and Ireland, later also Greece) showed much less enthusiasm for a Community without internal borders. ${ }^{35}$ Presumably, some of the countries which at that stage remained still outside the Community (in particular former EFTA members) were equally reluctant.

Since at that time differentiation within the Community was considered as neither desirable nor viable, the most willing member states started to cooperate on a flexible basis outside EC law. Cooperation started with a series of bilateral contacts, but continued soon on the basis of the more ambitious agenda established by the Schengen Agreement of 1985 . As a result of five years of negotiations, the latter was supplemented by the Schengen Implementation Agreement, which was signed in 1990, but entered into force only in 1995. Besides the abolition of internal border controls, the agenda of the five Schengen countries (France, Germany, Benelux) included an extensive list of related measures, such as the 
control of external borders, a common visa policy, coordination in the area of asylum, police cooperation, as well as the establishment of a network for the exchange of crimerelated information, the so-called Schengen Information System (SIS).

Before the Schengen acquis was eventually incorporated into EU law through the Amsterdam Treaty, eight more EU member states had joined the original five Schengen participants, leaving apart only the UK and Ireland. In fact, the UK was the only EU member that still remained unwilling to accept the Schengen acquis at Amsterdam. Ireland was willing but unable to participate fully, if the Common Travel Area with the UK was to be preserved. Denmark fully applies the substance of the Schengen acquis but is not obliged to participate in its further development under Title IV of the EC Treaty. All of these three countries with special rules applying to Title IV, however, have negotiated selective opt-in possibilities - including the UK. But the attraction of the cooperation that took off under the Schengen Agreements goes even beyond the external borders of the EU. Norway and Iceland implement the substance of the Schengen acquis, and Switzerland has - unsuccessfully so far - expressed a keen interest to participate.

Taking into account western Europe as a whole, the outcome at the end of the 1990s with respect to the Schengen acquis can therefore be summarised as follows: fifteen countries were eventually willing and able to participate (thirteen EU members plus Norway and Iceland), two were eventually willing but unable (Ireland, Switzerland), while only one was able but still unwilling (UK). Compared with the beginning in the mid-1980s, when only five countries were willing and able for Schengen, the Union is therefore relatively close to the re-establishment of unity with respect to the free movement of persons and related areas. From a small core, initially originating in bilateral coordination, the Schengen regime has grown even beyond EU borders. How can this eventual success despite initial reluctance be explained? 


\section{Explaining the success of Schengen: The role of the excludable SIS network}

As already mentioned above, Schengen included a variety of measures related to the free movement of persons. One of the core elements of the Schengen regime was the establishment of Schengen Information System (SIS), a database on wanted persons and objects, which became operational in $1995 .^{36}$ The SIS involves the pooling and common use of data collected at the national level. It is perhaps the most straightforward example of an excludable network good in the context of EU policies. Outsiders can be easily excluded while consumption is complementary, since the pooling of existing information involves hardly any additional costs, but increasing benefits as the number of participants grows.

With its relatively pure character of an excludable network good, very strong centripetal effects could theoretically be expected. In fact even Britain attempted to participate in the SIS at an early stage, though unsuccessfully, since it was still not willing to join the Schengen package as a whole (the Schengen countries refusing to de-link the two issues an option to which we will come back soon). ${ }^{37}$ Overall, it appears rather plausible that the excludable SIS network has contributed to a considerable extent to the centripetal effects of the Schengen package as a whole and to the willingness of some initially uninterested or reluctant countries to participate in the end.

\section{From Schengen to Dublin: An excludable network to prevent 'refugees in orbit'}

After having signed the Schengen Agreement of 1985, the five governments concerned established a negotiating structure for the elaboration of what finally became the Schengen Implementation Agreement of 1990, which included a working group on asylum. ${ }^{38}$ The eventual result in this area was a treaty chapter on the determination of the state responsible for examining any given application for asylum in the Schengen area. ${ }^{39}$ The objective was to prevent multiple applications in different Schengen countries by asylum seekers 'in orbit' ${ }^{40}$

The benefit of these provisions for Schengen participants was to be a reduction in the number of applications (although not necessarily in the number of applicants). Meanwhile, non-participants would remain excluded from such positive effects. Quite on the contrary, there was a looming danger of considerable negative external effects. Since second 
applications within the Schengen area became impossible, refugees would increasingly turn to non-Schengen countries. ${ }^{41}$ Moreover, with each increase in participants, the number of refugees applying in any given Schengen country after having been rejected in third countries outside Schengen was bound to decrease. Hence, consumption can be considered as complementary, while exclusion remains possible. Overall, the asylum provisions of the Schengen Implementation Agreement therefore had the characteristics of an excludable network good, although in a intuitively less obvious manner than the SIS, which was established by the same convention.

The centripetal dynamic triggered by the Schengen asylum provisions resembled those created by the SIS, but was ultimately channeled in a different way. Schengen participants allowed that the substance of the respective provisions eventually be superseded by the Dublin Convention, a separate legal instrument which could be joined independently by all Community members. Thanks to the eventual de-linkage of asylum rules from the Schengen acquis, their centripetal effects on outsiders can be better observed. Eventually, all EU member states signed the convention (Denmark only after the ministers of the other eleven member states made it explicit that they were ready to sign, after a specified delay, a convention excluding Denmark). ${ }^{42}$ Like in the SIS case, the attraction of what had once been initiated by Schengen participants eventually reached beyond EU borders. Sweden, Finland, Austria, Norway, Switzerland, certain central European countries, and even Canada showed their interest in joining the Dublin Convention or concluding parallel conventions. With their accession to the EU, the door for joining the Dublin Convention was finally opened to Sweden, Finland and Austria.

\section{CONCLUSIONS - IMPLICATIONS FOR EUROPEAN INTEGRATION}

Some of the most significant steps towards deeper integration in the 1990s were linked with flexible arrangements either within or outside the framework of EU law. This applies particularly to the three key policies first introduced by the Maastricht Treaty, i.e. monetary union (EMU), security and defence (WEU), as well as justice and home affairs (Schengen). However, the relation between integration, short run differentiation and long run unity have 
been surrounded by considerable uncertainty so far. Combining public goods theory with a framework for analysis developed by Schelling, the theory of differentiated integration presented in this contribution identifies potential effects of differentiation on integration and long run unity within the EU. In the short run, differentiation allows for more integration among the willing at the price of unity. Yet in the long run, unity may be re-established through centripetal effects which make initially reluctant countries join in eventually. According to the theory, centripetal effects depend on the character of the policy area in terms of public goods theory. They are expected to be strongest in the case of excludable networks and club goods, while being weak or even negative in the case of common pool resources.

But does the empirical evidence support the theory? The discussion of monetary union, Schengen-related policies and tax harmonisation suggests that the theoretically deduced mechanisms can indeed also be found in practice. The character of policies in terms of public goods theory may account for the eventual participation of initially reluctant countries in cases where alternative factors (such as genuine shifts in preferences, package deals, etc.) have difficulties in explaining the outcome. The Euro and the two Schengen-related subject matters entail certain (excludable) network effects and willing member states have successfully applied a flexible approach in these areas. Despite differentiation and reluctant member states in the beginning, the re-establishment of unity in the long run through the participation of most or all members is either a fait accompli or a likely outcome. By contrast, tax harmonisation involves a common pool resource, implying few incentives for outsiders to participate even in the long run. The anticipation of centrifugal effects, leading to the nonapplication of differentiation and the explicit attempts to include countries beyond EU borders in this important area, are fully in line with the logic of the theory.

Hence, because of their inherent centripetal effects on initially reluctant members, differentiated arrangements involving excludable network goods or club goods are likely to be more successful than those involving common pool resources or public goods. Up to a certain degree, policy-makers can influence and shape the character of policy areas by design. But where the concrete design cannot change the fundamental character of a common pool resource or a public good, partial integration of the willing is less likely to lead towards full 
integration (including initially unwilling countries). The difficulties to bring in everyone in the end might be so daunting that partial integration may not even go ahead in the first place.

For a long time, a strong current of economic thinking has justified the state as a provider of goods that individuals and markets fail to provide. Measured by these standards, a flexible EU lacks justification, since it may be unable to provide international public goods to and protect common pool resources of its member states. Problems like harmful tax competition or social and environmental dumping require other techniques to overcome deadlock. At the international level, package deals may be one of the few realistic alternatives. For a more ambitious Europe, and since "solving" public goods problems is a question of developing the appropriate political institutions ${ }^{43}$, the transition towards more majority decisions - in time including the constitutional level - could be a more effective alternative. However, by excluding precisely some of the above mentioned issues from the extension of qualified majority voting, Nice has dealt a blow to these hopes.

The outcome of the dynamic process of differentiated integration within the evolving constitutional framework of the EU will decide whether the emerging European state will in the long run be a novel polity (with overlapping, fluent borders around a vaguely defined core), or whether it will eventually find back to the more familiar kind of 'unity in diversity' embodied by traditional federal states (with similar rights and obligations for all constituents). The former scenario, close to the concept of 'Functional Overlapping Competing Jurisdictions' (FOCJ) developed by Bruno Frey and Reiner Eichenberger, would seriously prejudice the possibilities for collective action at the European level. ${ }^{44}$ It would reinforce regulatory competition while the provision of international public goods would tend to stagnate at a sub-optimal level. A polity based on unfettered flexibility risks to be a polity made up of loopholes. While this might be attractive for some, a proper debate has not yet taken place as to whether it would also be desirable from a democratic point of view, as well as supported by and beneficial to a majority of citizens.

This contribution has focused on the still poorly understood impact of short run differentiation on long run unity and integration across EU issue-areas and member states. Embracing yet more flexibility through the Nice Treaty while having scheduled an intergovernmental conference on possibly far-reaching constitutional issues for 2004, the European Union should give very careful attention to this issue. 
For their support at all stages of the research on which this article is based, I am particularly indebted to Daniel Verdier and Adrienne Héritier. Tanja Börzel, Christoph Engel, Katharina Holzinger and Markus Lehmann contributed important suggestions for changes to the original manuscript. I should also like to acknowledge further comments from Jim Bergeron, Dirk de Bièvre, Pieter Bouwen, Hervé Bribosia, Claus Giering, Mathias König-Archibugi, Jean-Victor Louis, Francesco Milner, Thomas Risse and Philippe Schmitter. Valuable insights originate in discussions with Christian Deubner, Claus Dieter Ehlermann, Francisco Fonseca Morillo, Dieter Freiburghaus, Thomas Gehring, Philipp Genschel, Walter Mattli, Lucio Pench, and Alexander Stubb. Finally, I would like to thank Margaret Percy for the correction of linguistic mistakes.

1. Throughout this article, the term European Union (EU) shall also include the European Communities (EC) as they already existed before the entering into force of the Maastricht Treaty (except for explicit references, e.g. to the Treaty on European Union).

2. For reasons of clarity, the terms member/membership shall uniformly cover involvement in the EU as such, whereas participant/participation refer to specific policies within the EU framework (e.g. EMU).

3. Concerning the terminology of differentiation see for example Tuytschaever, The Changing Conception of Differentiation in European Union Law, Dissertation (European University Institute 1998); A. Stubb, 'A Categorization Of Differentiated Integration', Journal of Common Market Studies 34/2 (1996), pp.283-95; and F. Chaltiel, 'Pour une clarification du débat sur l'Europe à plusieurs vitesses', Revue du Marché commun et de l'Union européenne 384 (Jan. 1995), pp.5-10. G. Edwards and E. Philippart, Flexibility and the Treaty of Amsterdam: Europe's New Byzantinum, University of Cambridge, CELS Occasional Paper 3 (Cambridge: Cambridge University Press, 1997), p.1, have rightly stated that '[...] flexibility is a concept replete with terminological and semantic confusion', a view which is also shared by other authors. In this contribution, only the two general terms 'differentiation' and 'flexibility' shall be used, though further specified with reference to specific criteria if necessary.

4. Of course, certain limited elements of legal differentiation have always existed in EC law - see E. Grabitz and C. Iliopoulos, 'Typologie der Differenzierungen und Ausnahmeregelungen im Gemeinschaftsrecht', in Grabitz (ed.), Abgestufte Integration: Eine Alternative zum herkömmlichen Integrationskonzept?, (Kehl am Rhein/Strasbourg: N.P. Engel Verlag 1984), pp.31-46; C.D. Ehlermann, 'Différenciation accrue ou uniformité renforcé', Revue du Marché Unique Européen 3 (1995), pp.19697; F. Tuytschaever, The Changing Conception of Differentiation, pp.7-24.

5. The figure shows ideal types, and examples should therefore be considered as mere illustrations. The blank vertical columns symbolise the parts and their competencies (for instance the UK in the case of the EU or California in the case of the US), whereas the hatched grey areas stand for the common institutions and competencies. The graphic representation of flexibility reflects quite literally the term 'Abgestufte Integration' used by Grabitz (ed.), Abgestufte Integration.

6. On the effects of differentiation on further integration see for example H. Wallace and A. Ridley, Europe: The Challenge of Diversity, Chatham House Papers 29, The Royal Institute of International Affairs, London: Routledge, 1985, pp.66-81; U. Becker, 'Differenzierung der Rechtseinheit durch "Abgestufte Integration", Europarecht Supplement 1 (1998), pp.39-41; W. Wessels and B. Jantz, 'Flexibilisierung: Die Europäische Union vor einer neuen Grundsatzdebatte? Grundmodelle unter der Lupe', in R. Hrbek (ed.), Die Reform der Europäischen Union (Baden-Baden: Nomos 1997), pp.34568; Edwards and Philippart, Flexibility and the Treaty of Amsterdam, p.35-41; E. Philippart and G. Edwards, 'The provisions on closer co-operation in the Treaty of Amsterdam: The politics of flexibility in the European Union', Journal of Common Market Studies 37/1 (March 1999), pp.102-106.

7. See for instance A. Moravcsik and K. Nicolaïdis, 'Explaining the Treaty of Amsterdam: Interests, Influence, Institutions', Journal of Common Market Studies 37/1 (Dec. 1999), pp.59-85; A. Moravcsik, 'Negotiating the Single European Act: National Interests and Conventional Statecraft in the European Community', International Organization 45/1 (Winter 1991), pp.19-56; A. Moravcsik, 'Preferences and Power in the European Community: A Liberal Intergovernmental Approach', Journal of Common Market Studies 31/4 (Dec. 1993), pp.473-524; P. Pierson, 'The Path of European Integration: A Historical Institutionalist Approach', Comparative Political Studies, 29/2 (April 1996) pp.123-63; W. Mattli, The Logic of Regional Integration: Europe and Beyond (Cambridge: Cambridge University Press 1999). An interesting approach for explaining the effects of 'sequential' vs. 'inclusive' treaty formation on the eventual level of integration, which could potentially be applied to flexible integration, has been developed by A. Downs et al., 'Managing the Evolution of Multilateralism', International Organization 52/2 (Spring 1998), pp.397-419. 
8. For an attempt to identify areas of potentially successful future differentiation while taking into account insights of this theory, see F. Milner and A. Kölliker, How to Make Use of Closer Cooperation? The Amsterdam Clauses and the Dynamics of European Integration, Forward Studies Unit Working Paper (Brussels: European Commission 2000), published under www.europa.eu.int/comm/cdp/workingpaper/cooperation.pdf. See in this context also C. Deubner, Harnessing Differentiation in the EUFlexibility after Amsterdam, Forward Studies Working Paper (Brussels: European Commission 2000), published under www.europa.eu.int/comm/cdp/working-paper/enhanced_flexibility.pdf.

9. See T.C. Schelling, Micromotives and Macrobehavior (New York: Norton 1978).

10. An an early stage, Mancur Olson has referred to 'external benefits' from goods produced within a given jurisdiction, spilling beyond the particular boundaries thereof. See M. Olsen, 'Strategic Theory and Its Application', The American Economic Review 59/2 (May 1969), pp.486-87. On external effects of integration, see Mattli, The Logic of Regional Integration, pp.59-64.

11. Exclusion may be technically impossible, prohibitive in terms of economic costs, or defined and enforced by law. Duncan Snidal has pointed to the consequences such distinctions imply, focusing in particular on the notion of property rights. See D. Snidal, 'Public Goods, Property Rights, and Political Organizations', International Studies Quarterly 23/4 (Dec. 1979), pp.532-66.

12. The terminology is not uniform. Some authors refer also to 'jointness in consumption', 'marginal costs of an additional unit of consumption', 'subtractability', or 'increasing returns to consumption'. See R. Gardner et al., 'The nature of the common-pool problem', Rationality and Society 2/3 (July 1990); E. Ostrom et al., Rules, Games, and Common-Pool Resources (Ann Arbor: University of Michigan Press 1994); P. Krugman, 'Entertainment Values: Will Capitalism go Hollywood?', Slate - The Dismal Science 22 (Dec. 1998).

13. However, club theory usually assumes that rivalry of consumption starts in the form of 'congestion' as soon as the number of participants in a club crosses a certain threshold. To the extent that the theory, which shall be developed is about pure goods, my definition of club goods is distinct from the standard definition. According to this definition, rivalry in consumption is low independently of the number of participants.

14. This applies in particular to exclusive groupings of economically or otherwise powerful states such as G8 or the OECD. For an analysis of regional agreements as clubs see P.C. Padoan, 'Political Agreements as clubs: The European case', in D. Mansfield and H.V. Milner (eds.), The Political Economy of Regionalism (New York: Columbia University Press 1997), pp.107-33.

15. Excludable arrangements for insurance and mutual defence have been discussed as goods with complementary consumption by Snidal, 'Public Goods', pp.563-64. Most literature refers to 'network effects' of specific goods rather than 'network goods' as such.

16. On Schengen and the SIS see for example T. Gehring, 'Die Politik des koordinierten Alleingangs', Zeitschrift für Internationale Beziehungen 5/1 (June 1998), pp.43-78.

17. For a more in-depth theoretical and empirical analysis of common pool resources and the specific problems which are inherent in the management of common pool resources under the condition of voluntary cooperation see Ostrom, Governing the Commons (Cambridge: Cambridge University Press 1990); Ostrom et al., Rules, Games, and Common-Pool Resources, and Gardner et al., 'The Nature of the Common-Pool Problem'.

18. A comprehensive overview on regulatory competition across various issue-areas in the US and the EU is given by D.C. Esty and D. Gerardin (eds.), Regulatory Competition and Economic Integration: Comparative Perspectives (Oxford: Oxford University Press 2001).

19. V.H. Dehejia and P. Genschel, 'Tax Competition in the European Union', Politics and Society 27/3 (Sept. 1999), p.426, argue partly in the same direction. See also P.M. Huber, 'Differenzierte Integration und Flexibilität als neues Ordnungsmuster der Europäischen Union', Europarecht 31/4 (Oct. 1996), p.357, and W. Wessels, 'Der Amsterdamer Vertrag: Durch Stückwerksreformen zu einer effizienteren, erweiterten und föderaleren Union?', Integration 20/3 (Aug. 1997), p.129.

20. Following and developing Snidal, 'Public Goods', as well as P. Genschel, and T. Plümper, 'Regulatory Competition and International Co-operation', Journal of European Public Policy 4/4 (Dec. 1997), pp.626-42, Thomas Gehring, 'Die Politik des koordinierten Alleingangs', has explicitly or implicitly used certain elements of public goods theory (such as excludability, rivalry in consumption, club goods and public goods) when discussing the development of the Schengen regime.

21. The utility of cooperation (respectively non-cooperation) as represented in Schelling's diagrams corresponds to what I have defined as the internal effects (respectively external effects) of cooperation. 
22. However, this does not necessarily mean that initially unwilling countries always prefer the full integration of all members (including themselves) to the status quo ante (where none of the members have integrated their policies). Negative external effects produced by the flexible cooperation of the willing may tilt the balance toward participation even for countries which would prefer the status quo ante.

23. This assumption is compatible with Kuran's bandwagoning approach - see R. Cornes and T. Sandler, The Theory of Externalities, Public Goods and Club Goods (Cambridge: Cambridge University Press 1996). Based on divergent utility functions for the different countries concerned, this approach explains when countries start to cooperate, depending on the number of other participants. But while the character of the good gives at least a partial explanation of the position of the utility functions, the latter seem to be completely exogenous in the bandwagoning approach.

24. This analysis is based on the assumption that the overall quantity of the collectively provided good is held constant, while the costs and utility for each of the participants may vary according to the character of the good and the number of consumers.

25. Snidal, 'Public Goods', p.543, has used the term 'zone of no production' in this context. Health care is one of the few fields in which public policies actively produce common pool resources, a fact which might well explain the recurrent problem of rapidly increasing costs in this specific area.

26. In the following, the term EMU will usually refer to the third stage of EMU as defined by the Maastricht Treaty.

27. See European Commission, 'One Market, One Money. An Evaluation of the Potential Benefits and Costs of Forming an Economic and Monetary Union', European Economy 44 (October 1990), pp.23544.

28. Up to a certain degree, this pattern was also reflected in public opinions on the matter. Even long after the coming into force of the Maastricht Treaty, the opinion polls revealed still predominantly hostile attitudes towards the replacement of national currencies in the UK, Denmark, Austria, Finland, Sweden, but also Germany. In Portugal and Greece support for EMU figured among the lowest with respect to the remaining, more favourable countries. See European Commission, Eurobarometer 44 (Luxembourg: Office for Official Publications of the European Communities 1996), p.49.

29. See for instance European Commission, Eurobarometer 44; P. de Grauwe, The Economics of Monetary Integration (Oxford: Oxford University Press 1994); C. Taylor, EMU 2000? Prospects for European Monetary Union (London: The Royal Institute of International Relations 1995); M. Crawford, One Money for Europe? The Economics and Politics of EMU (London: Macmillan 1996).

30. On the network effects of a common currency see Taylor, EMU 2000?, pp.26-27; K. Dowd and D. Greenaway, 'Currency Competition, Network Externalities and Switching Costs: Towards an Alternative View of Optimal Currency Areas', Economic Journal 103/5 (Sept. 1993), p.1180.

31. See in this context also Taylor, EMU 2000?, pp.56-58; Federal Trust, Towards the Single Currency. The Intergovernmental Conference of the European Union 1996 (London: PSI Publishing 1995), pp.20-22; and Moravcsik, 'Preferences and Power in the European Community', p.493.

32. Based on a specifically developed model of tax competition, Dehejia and Genschel, 'Tax Competition in the European Union', p.421, have argued that '[p]artial integration is collectively immiserizing for the cooperators.' In this context, it is important to note that benefits for non-cooperators with low or zero tax rates may be indirect, e.g. when capital inflows lead to lower interest rates or increased employment in the banking sector.

33. Feira European Council, Presidency Conclusions, 19 and 20 June 2000, Annex IV.

34. With respect to the efforts at the level of the OECD, see the relevant documents, including the 'OECD Model Tax Convention on Income and on Capital', published under www.oecd.org. The OECD, EMU Facts, Challenges and Policies (Paris: OECD 1999), p.86, has also argued that cooperation of EU member states in this field 'may not work well in the absence of wider multilateral agreements.'

35. See Gehring, 'Die Politik des koordinierten Alleingangs', pp.48-49.

36. See Title IV (Art. 92-119) of the Schengen Implementation Agreement.

37. See Gehring, 'Die Politik des koordinierten Alleingangs', p.66.

38. See G. Renault, 'Schengen, un modèle pour l'Europe pénale?', Les Dossiers du Journal des Tribunaux 6 (1995), pp.49-50.

39. See Title II, Chapter 7 (Art. 28-38) of the Schengen Implementation Agreement. 
40. See J.J. Bolten, 'From Schengen to Dublin: The New Frontiers of Refugee Law', in H. Meijers et al., Schengen - Internationalisation of central chapters of the law on aliens, refugees, privacy, security and the police (Leiden: Kluwer 1991), pp.8-36.

41. On potential external effects on Switzerland, see P. Garrone, 'Swiss Asylum Policy Faced with the Schengen and Dublin Conventions', in G.D. Korella and Patrick M. Twomey (eds.), Towards a European Immigration Policy (Brussels: European Interuniversity Press 1993), pp.217-26.

42. See the respective declarations in the minutes of the conference of immigration ministers of EC member states (Dublin, 15 June 1990), reproduced in E. Guild (ed.), The Developing Immigration and Asylum Policies of the European Union (The Hague: Kluwer Law International 1996), pp.87-89. It may appear contradictory that the Dublin Convention was signed even four days earlier than the Schengen Implementation Agreement, on 15 June 1990. However, it remains an undisputed fact that Dublin is a result of Schengen, not vice versa. To begin with, the elaboration of the Schengen provisions began much earlier. Moreover, those provisions also served as a model for the nearly identical Dublin Convention - see V. Hreblay, Les accords de Schengen: Origine, fonctionnement, avenir (Brussels: Bruylant 1998), p.78. Finally, the Schengen Implementation Agreement became operational on 26 March 1995, that is, more than two years before the Dublin Convention (1 September 1997).

43. Snidal, 'Public goods', p.564.

44. See B. Frey and R. Eichenberger, 'FOCJ: Competitive Governments for Europe', International Review of Law and Economics 16 (1997), pp.315-327, and R. Eichenberger, 'Eine "fünfte Freiheit" für Europa: Stärkung des politischen Wettbewerbs durch "FOCJ", Zeitschrift für Wirtschaftspolitik 45 (1996), pp.110-130. 